\title{
Actinomycetes from Soil of Lachung, a Pristine High Altitude Region of Sikkim Himalaya, Their Antimicrobial Potentiality and Production of Industrially Important Enzymes
}

\author{
Laishram Shantikumar Singh1*, Hemant Sharma1, Dinabandhu Sahoo² \\ ${ }^{1}$ Institute of Bioresources and Sustainable Development, Sikkim Centre, DBT, Gangtok, India \\ ${ }^{2}$ Institute of Bioresources and Sustainable Development, DBT, Imphal, India \\ Email: *shantiks@rediffmail.com
}

How to cite this paper: Singh, L.S., Sharma, H. and Sahoo, D. (2019) Actinomycetes from Soil of Lachung, a Pristine High Altitude Region of Sikkim Himalaya, Their Antimicrobial Potentiality and Production of Industrially Important Enzymes. Advances in Microbiology, 9, 750-773.

https://doi.org/10.4236/aim.2019.98046

Received: July 16, 2019

Accepted: August 13, 2019

Published: August 16, 2019

Copyright $\odot 2019$ by author(s) and Scientific Research Publishing Inc. This work is licensed under the Creative Commons Attribution International License (CC BY 4.0).

http://creativecommons.org/licenses/by/4.0/

\begin{abstract}
Investigations on actinomycetes are profoundly significant area of research since they form major resource for bioactive compounds, antimicrobials, anticancer agents, immunosuppressants, and biological control agents. A total of 59 actinomycetes were isolated from the soil sample collected from Domang, Lachung, North Sikkim, Sikkim, India. Out of the total isolates, 26 isolates with unique and distinct characteristic features were selected and analysed for antimicrobial activity as well as extracellular enzyme production. Out of 26 isolates, 17 (66\%) isolates exhibited different level of growth inhibition against the test microorganism. $12(47 \%)$ isolates showed antifungal activity and six (23\%) isolates showed antibacterial activity. Most of the isolates showed antifungal activity. Isolate RCS260 was found to exhibit maximum growth inhibition (60\%) against Colletotrichum gloeosporioides MTCC 8021. Isolate RCS252 showed maximum growth inhibition (67\%) against Bacillus subtilis MTCC 441. Out of 26 isolates, 14 (54\%) isolates exhibited chitinase activity, 25 (96\%) isolates showed cellulase production, 20 (77\%) isolates produced amylase enzyme and 17 (65\%) isolates showed positive for protease activity. Potential isolate RCS260 has been characterized and identified as Streptomyces vinaceus strain RCS260 while isolate RCS252 was identified as Kitasatospora aburavienis strain RCS252. The antagonistic profile of strain RCS260 highlights its potential as antifungal agent against phytopathogens.
\end{abstract}

\section{Keywords}

Actinomycetes, Antimicrobial Activity, Extracellular Enzyme Production 


\section{Introduction}

Actinomycetes are filamentous bacteria possessing high $\mathrm{G}+\mathrm{C}$ content $(>55$ mol\%) in their nucleic acid. The metabolic diversity of actinomycetes is mainly because of large genome having many transcription factors which enable them to direct gene expression according to precise requirements [1]. They are ubiquitous organisms with wide physiological and morphological diversity and have been isolated from all kinds of terrestrial and aqueous habitats where they can exist as free-living bacteria as well as pathogens [2] or in symbiotic associations with plants [3] and insects [4] or as endophytes [5]. The genus Streptomyces is dominant among the actinomycetes. They are largely exploited for their capability to produce variety of secondary metabolites including antibacterials [6], antifungals [7], antivirals [8], antitumor [9], anti-hypertensives [10], immunosuppressives [11] and plant growth promoting factors [12]. Streptomyces is the most prominent among all the actinomycetes with regard to production of antibiotics which accounts to about $75 \%$ of commercially used and almost half of the antibiotic compounds identified so far [13]. Actinomycetes exhibiting antimicrobial activity have been reported from Phoomdi, Loktak Lake, Manipur, India [14]. S. tanashiensis strain A2D was reported to possess significant antimicrobial activity [15]. Our group has also reported the isolation of $S$. sannanensis strain SU118 and production of antimicrobial agent [16]. They are also exploited for various enzymes of commercial importance [17] [18] [19] [20]. They produce several enzymes including chitinase, pectinase, amylase etc. which are of significant values in industries. Apart from their values in industries, these enzymes play a major role in bioremediation of recalcitrant substances and to uphold the biogeochemical cycle [21] [22]. Several species of Streptomyces are also responsible for decomposing organic molecules like cellulose, lignin, hemicelluloses, chitin and other recalcitrant compounds [13]. Chitin is one of the most abundant polysaccharides found on this planet. Chitinolytic enzymes are responsible for degradation of chitins available in nature. Chitinases have been found to be responsible for the breakdown of chitin which is present in the cell wall of fungi. Their potential role as a biocontrol agent against fungal phytopathogens is of considerable interest in organic farming system. Chitinase from one of the strains of actinomycetes, $S$. griseus HUT6037, has been found to increase plant resistance to disease caused by Trichoderma reesei [23]. Our group has reported the chitinolytic activity of Streptomyces sp. MT7 and its antagonistic activity against wood-rotting fungi [24]. Keeping in view of the fact that in spite of massive exploration of actinomycetes for different functionalities in earlier times, the investigation for potent organism possessing distinctive characteristics still holds to be fascinating field of research. During the process of search for effective metabolites, many studies have been targeted in isolating novel actinomycetes from unique and virgin habitats. Even though terrestrial habitats have been explored by several researchers for many years, it is pertinent to highlight that the actinomycetes discovered so far is very meagre [25]. Studies on actinomycetes from 
untapped environments have attracted noteworthy interest in the present time for the production of secondary metabolites and other functionalities. The growing inventory of novel actinomycetes and the outcomes obtained from lesser studied areas such as Antarctica [26] as well as some habitats of Manipur [14] [15] [16] imply that a vigilant investigation of new environment might lead to be valuable. Such work on screening of actinomycetes capable of producing bioactive metabolites is of immense importance that would lead to the development of effective antifungal as biocontrol agent towards the fight against phytopathogens causing diseases in crop plants. Biocontrol agents offer safer alternatives compared to the chemicals which are hazardous. This investigation is a component of our continuing effort for screening of actinomycetes from pristine locations of north east region of India within the Eastern Himalayan biodiversity hot-spot so as to comprehend the microbial resources and their worthiness to the society. This study focus on the exploration and screening the actinomycetes from rhizosphere soil of Panax bipinnatifidus from Lachung, a high altitude region of North Sikkim, Sikkim, India for their antimicrobial activity and their capability to produce some important industrial enzymes.

\section{Materials and Method}

\subsection{Location and Sample Collection}

Lachung, a mountain village close to the Tibetan border, in the northeastern Indian state of Sikkim in the North Sikkim district is located about $118 \mathrm{~km}$ from Gangtok. It is divided by the Lachung River. The picturesque valley, also known for its pine forest, waterfalls, hot springs, serene environment, pristine habitats is part of the Eastern Himalayan Biodiversity Hot Spot region. Soil samples were collected from a depth of $5-10 \mathrm{~cm}$ from the rhizosphere of Panax bipinnetifidus from Domang area, a pristine ecological niche of Lachung (Latitude: $27^{\circ} 41^{\prime} 20.61^{\prime \prime N}$; Longitude: $88^{\circ} 44^{\prime} 34.7^{\prime \prime E}$; Altitude: 3114 meters, Average temperature: $14.3^{\circ} \mathrm{C}$; Annual rainfall: $1094 \mathrm{~mm}$ ). Three samples each of about $50 \mathrm{~g}$ were collected from the three sites approximately 5 meters apart. The samples were kept in sterile container after collection using sterile spatula and brought to the laboratory for study. The three samples were pooled together and mixed. Figure 1 shows the sampling site of the study area.

\subsection{Culture Media for Isolation}

The following media with the mentioned components were used during the isolation of actinomycetes. Starch casein agar (SCA): Soluble starch-10.0 g; Casein-0.3 g; $\mathrm{KNO}_{3}-2.0 \mathrm{~g} ; \mathrm{NaCl}-2.0 \mathrm{~g} ; \mathrm{K}_{2} \mathrm{HPO}_{4}-2.0 \mathrm{~g} ; \mathrm{MgSO}_{4} \cdot 7 \mathrm{H}_{2} \mathrm{O}-0.05 \mathrm{~g} ; \mathrm{CaCO}_{3}-0.02$ g; $\mathrm{FeSO}_{4} \cdot 7 \mathrm{H}_{2} \mathrm{O}-0.01 \mathrm{~g}$; Agar-20.0 g; distilled water-1000.0 ml; pH-7.0. Casein Starch Peptone Yeast extract Malt extract agar (CSPY-ME): $\mathrm{K}_{2} \mathrm{HPO}_{4}-0.5$ g; Casein-3.0 g; Soluble starch-10.0 g; Peptone-1.0 g; Yeast extract-1.0 g, Malt extract-10.0 g; Agar-20.0 g; distilled water-1000.0 ml, pH-7.5. Streptomyces Agar (SA) (HiMedia Laboratories Pvt. Limited, Mumbai, India); 


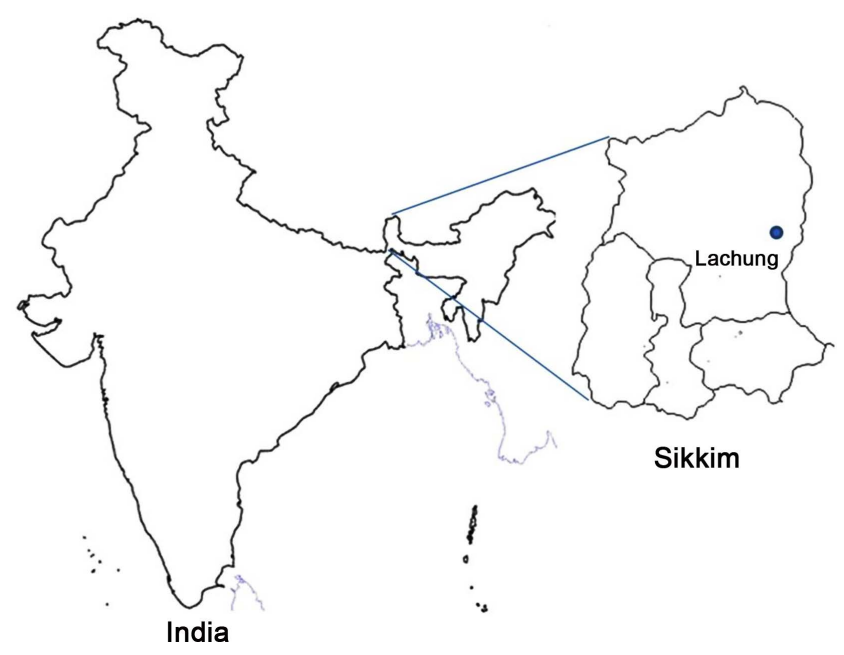

Figure 1. Location of sampling site, Lachung, North Sikkim, Sikkim, India.

Actinomycete Isolation Agar (AIA) (HiMedia, Laboratories Pvt. Limited, Mumbai, India).

\subsection{Test Microorganisms}

Colletotrichum gloeosporioides MTCC8021, C. capsici MTCC3414, C. acutatum MTCC2213, Bacillus subtilis MTCC441 and Escherichia coli MTCC739 procured from Microbial Type Culture Collection Centre, CSIR-Institute of Microbial Technology (IMTECH), Chandigarh, India while C. gloeosporioides ITCC 5514 procured from Division of Plant Pathology, Indian Agriculture Research Institute, Pusa campus, New Delhi were used for detection of antimicrobial activity of the actinomycetes during the investigation.

\subsection{Pretreatment of Soil Sample and Isolation of Actinomycetes}

The pooled and mixed sample was air dried sufficiently for a week time. $1.0 \mathrm{~g}$ of the dried sample was taken and treated with $0.1 \mathrm{~g}$ of $\mathrm{CaCO}_{3}$ and kept at room temperature for 7 days so as to enrich actinomycetes that generally prefer alkaline $\mathrm{pH}$ [27]. $1.0 \mathrm{~g}$ of the treated sample was then added to $99.0 \mathrm{ml}$ of sterile distilled water and placed in a shaking incubator maintained at $28^{\circ} \mathrm{C}$ with shaking speed of $140 \mathrm{rpm}$ for one hour. The mixture was then allowed to settle down. 1.0 $\mathrm{ml}$ from the suspension was taken and then subjected to serial dilution up to $10^{-5}$ dilutions. $0.2 \mathrm{ml}$ from $10^{-3}, 10^{-4}$ and $10^{-5}$ dilutions were taken and plated in duplicates on SCA, CSPY-ME agar, SA and AIA plates which were previously added with $100 \mu \mathrm{g} / \mathrm{ml}$ Cycloheximide and $50 \mu \mathrm{g} / \mathrm{ml}$ Nalidixic acid by adopting spread plate technique [28]. The plates were incubated for 10 days at $28^{\circ} \mathrm{C}$. Individual colonies having characteristics features of actinomycetes were isolated after incubation. The isolates were streaked repeatedly on the respective agar plates so to obtained pure cultures. The cultures of the selected pure isolates were transferred to agar slants and stored at $4^{\circ} \mathrm{C}$. The selected pure isolates were then studied for antimicrobial activity against test microorganisms and also evaluated for 
production of extracellular enzymes. For long term preservation and future use the purified actinomycete colonies were scraped from agar plates by sterile blunt tips using a glycerol buffer solution and one $\mathrm{ml}$ of buffer-actinomycete suspension was transferred to sterile cryo-vials and stored at $-80^{\circ} \mathrm{C}$.

\subsection{In-Vitro Antimicrobial Activity of the Isolates}

\subsubsection{Antibacterial Activity}

The selected actinomycete isolates were evaluated for antibacterial activity by adopting spot inoculation technique [14]. Each pure isolates were spot inoculated in the centre of the SCA plate and incubated for seven days at $28^{\circ} \mathrm{C}$. After incubation the colonies were covered with a $0.6 \%$ agar layer of nutrient agar (NA) earlier added with the test bacterial (B. subtilis MTCC441and E. coli MTCC739) suspensions having $1.5 \times 10^{8}$ colony forming units $(\mathrm{CFU}) / \mathrm{ml}$ in normal saline [29]. The plates were then incubated for $24 \mathrm{~h}$ at $37^{\circ} \mathrm{C}$. After incubation the zone of growth inhibition of the test bacterial strain around the actinomycete isolates was examined. The evaluation was performed in triplicates. The percentage inhibition of growth of the test bacteria was calculated according to de Oliveria et al. [30] and recorded.

\subsubsection{Antifungal Activity}

The actinomycete isolates were evaluated for in-vitro antagonistic activity towards $C$. gloeosporioides, the blight pathogen of Amomun subulatum (Large cardamom) as well as other phytopathogens by adopting dual culture assay method [31] with little modification. A loopful of spore suspension $\left(10^{6} \mathrm{spores} / \mathrm{ml}\right)$ of the actinomycete isolates was inoculated on one side of Potato Dextrose Agar (PDA) plate and incubated for 5 days at $28^{\circ} \mathrm{C}$. At this time the colonies had become distinctly visible and sporulated. Fungal mycelial plug of $5.0 \mathrm{~mm}$ diameter from $72 \mathrm{~h}$ old culture of $C$. gloeosporioides grown on PDA was cut and transferred to the other side of the PDA plate already grown with the actinomycete isolate. The fungal mycelial plug placed on PDA plates uninoculated with actinomycetes serve as control. The plates were further kept for incubation for 5 days at $28^{\circ} \mathrm{C}$. The radial fungal growth in the direction of the antagonist in the dual culture plates as well as in the control was measured after incubation. Growth inhibition was considered when the growth of the fungal mycelium in the direction of the actinomycete colony was hindered or prevented. All the evaluation was performed in triplicates. Similarly the antagonistic activity of the actinomycete isolates was also performed against other phytopathogens. The percentage growth inhibition of the pathogens was calculated according to the method reported by Zivkovic et al. [32].

\subsection{Screening for Production of Extracellular Enzymes by the Isolates}

\subsubsection{Chitinase Detection}

The chitinolytic property of the actinomycetes was detected by adopting the method of Nagpure et al. [24]. The isolates were spot inoculated by a loop at the 
centre of the basal salt agar medium having the following composition (in $\mathrm{g} / \mathrm{L}$ of distilled water): $\mathrm{K}_{2} \mathrm{HPO}_{4}$ 0.7, $\mathrm{KH}_{2} \mathrm{PO}_{4} 0.3, \mathrm{MgSO}_{4}$ 0.5, $\mathrm{FeSO}_{4} 0.01, \mathrm{ZnSO}_{4} 0.001$, $\mathrm{MnSO}_{4} 0.001,\left(\mathrm{NH}_{4}\right)_{2} \mathrm{SO}_{4} 0.25$, Agar 20.0, yeast extract $1.0 \%$ and $1.0 \%$ colloidal chitin. To detect chitinase activity the plates were incubated at $28^{\circ} \mathrm{C}$ for 7 days and then the agar plates were flooded with an aqueous solution of $0.1 \%(\mathrm{w} / \mathrm{v})$ Congo red for $40 \mathrm{~min}$. Congo red solution was then poured off and destained with $1 \mathrm{M} \mathrm{NaCl}$ for $20 \mathrm{~min}$. Any clearance zone thus formed around the colony indicates positive for the production of chitinase enzyme was observed and recorded.

\subsubsection{Cellulase Detection}

The detection of cellulase enzyme production was carried out by adopting the method of Kasana et al. [33]. The isolates were inoculated in basal salt agar medium containing 0.5\% Carboxy Methyl Cellulose (CMC). The plates were incubated at $28^{\circ} \mathrm{C}$ for 7 days. Upon incubation the plates were then flooded with Gram's iodine and observed after 5 minutes. Gram's iodine forms a bluish black complex with cellulose but not with hydrolysed cellulose, thereby producing a distinct clear zone around the cellulase producing isolates. Plates without the CMC (non-substrate) were used as controls in all experiments. Formation of clear zone indicates positive for cellulase production by the isolates which were recorded.

\subsubsection{Amylase Detection}

Detection of amylase production was carried out according to Rengasamy \& Thangaprakasam [34] using Starch agar medium (HiMedia Laboratories Pvt. Limited, Mumbai, India) containing $0.2 \%$ soluble starch. The actinomycete isolates were inoculated in starch agar plate and incubated at $28^{\circ} \mathrm{C}$ for 7 days. After incubation $3 \mathrm{ml}$ of $1 \%$ iodine was flooded in each plate and then development of a zone around the colonies indicated the production of amylase. Iodine forms a bluish black complex with starch but not with hydrolysed starch, thereby producing a clear zone around the amylase producing isolates. Development of clear zone indicates positive for amylase production and the results were recorded.

\subsubsection{Protease Detection}

The detection of protease enzyme production by the actinomycete isolates were performed according to the method described by Jeyadharsan [35] using Skim milk agar medium (HiMedia Laboratories Pvt. Limited, Mumbai, India) containing $2.8 \%$ skim milk powder. The actinomycete isolates were inoculated in the centre of Casein agar plate and incubated at $28^{\circ} \mathrm{C}$ for 7 days. After incubation the plates were observed for the development of zone of clearance around the colony. The enzyme activity was visualized as a clear zone of substrate utilization and the results were recorded.

\subsection{Siderophores Production}

The production of siderophores by the actinomycete isolates were evaluated ac- 
cording to the methods of Beneduzi et al. [36] Pure actinomycete isolates were spot inoculated on King's B medium supplemented with a complex chrome azurol $\mathrm{S}$ [CAS/Iron (III)/hexadecyltrimethyl ammonium bromide]. The plates were incubated at $28^{\circ} \mathrm{C}$ for $7-10$ days. The isolates that were able to produce siderophores grew and formed a yellow halo in the blue coloured medium after the iron chelation by siderophores. Thus the actinomycete isolates that showed yellow zone were recorded as positive for siderophores production.

\subsection{Characterisation of the Actinomycetes}

\subsubsection{Morphological and Cultural Characteristics}

The colony features, cultural characteristics and the diffusible pigments of all isolates were studied and observed by culturing for 14 days on medium like ISP-2 (in g/L of distilled water: Malt extract 10.0, Yeast extract 4.0, Dextrose 4.0, agar 20.0, $\mathrm{pH}$ 7.2); ISP-4 (in g/L of distilled water: Soluble starch 10.0, $\mathrm{K}_{2} \mathrm{HPO}_{4} 1.0, \mathrm{MgSO}_{4}$ 1.0, $\left(\mathrm{NH}_{4}\right)_{2} \mathrm{SO}_{4} 2.0, \mathrm{CaCO}_{3} 2.0, \mathrm{FeSO}_{4} \cdot 7 \mathrm{H}_{2} \mathrm{O} 0.001, \mathrm{MnCl}_{2} 0.001, \mathrm{ZnSO}_{4} 0.001$, agar 20.0, pH 7.2) according to International Streptomyces Project (ISP) [37]. The morphological characteristics were studied by using cover slip culture method in which the culture was transferred to the base of cover slips buried at an angle of $45^{\circ}$ in SCA medium [16] and incubated at $28^{\circ} \mathrm{C}$ for 10 days. The characters such as aerial mycelia, spore arrangements, morphology of spore bearing hyphae with entire spore chain was then studied as described in Bergey's manual [38] by observing under phase contrast microscope.

\subsubsection{Identification of the Potential Actinomycete Strains}

The two potential strains namely RCS252 and RCS260 were identified by adopting polyphasic approach including cultural characteristics, morphological, biochemical characteristics and molecular method by the $16 \mathrm{~S}$ rRNA gene sequencing. Utilization of different carbon sources was carried out by growth on ISP9 [39] supplemented with $1 \%$ carbon source at $28^{\circ} \mathrm{C}$. Temperature range, $\mathrm{pH}$ range and $\mathrm{NaCl}$ tolerance for growth have been evaluated on ISP4 by growing the two isolates separately at different temperatures $\left(20^{\circ} \mathrm{C}-42^{\circ} \mathrm{C}\right), \mathrm{pH}(5-10)$ and $\mathrm{NaCl}$ concentration $(1 \%-5 \% \mathrm{NaCl})$ respectively. Starch hydrolysis, Gelatine Liquefaction as well as other biochemical tests was performed according to the protocol described by Gordon et al. [40]. Nitrate reduction test were evaluated by adopting the procedure of ISP [37]. Evaluation for meso and LL-Diaminopimelic acid (LL-DAP) were performed by following the method of Becker et al. [41] and Lechevalier and Lechevalier [42]. The results of all the experiments were observed and noted down after incubation for seven days.

\subsubsection{Genomic DNA Isolation and Amplification of $16 \mathrm{~S}$ rDNA Gene}

The two actinomycetes strains namely RCS252 and RCS260 were grown in $5 \mathrm{ml}$ Soyabean Casein Digest medium by incubating in a shaking incubator at $28^{\circ} \mathrm{C}$ for 7 days with agitation at $140 \mathrm{rpm}$. Genomic DNA of the strains was extracted separately by adopting phenol-chloroform method [43]. The $16 \mathrm{~S}$ rDNA gene amplification of the two strains was carried out separately. Fragment of $16 \mathrm{~S}$ rDNA gene of 
the strain RCS252 was amplified by $27 \mathrm{~F}$ and 1492R primers while amplification of $16 \mathrm{~S}$ rDNA gene of the strain RCS260 was done by ACT283F and ACT1360R primers. The gene amplification were performed in thermal cycler (Bio-Rad, USA) in a final volume of $25 \mu \mathrm{l}$ [reaction mixture containing $0.625 \mu \mathrm{l}$ of each forward and reverse primer (10 $\mu \mathrm{M}$ each), $1.0 \mu \mathrm{l}$ of template DNA, $2.5 \mu \mathrm{l}$ of $10 \times$ reaction buffer, $1.0 \mu \mathrm{l}$ of $\mathrm{MgCl}_{2}(25 \mathrm{mM}), 0.30 \mu \mathrm{l}$ (5 unit/ $\left.\mu \mathrm{l}\right) \mathrm{DNA}$ polymerase and sterilized Mili-Q grade water to makeup volume up to $25 \mu \mathrm{l}$ ]. In the PCR process the thermal cycle was set as initial denaturation at $94^{\circ} \mathrm{C}$ for $10 \mathrm{~min}$, followed by 36 cycles of denaturation at $94^{\circ} \mathrm{C}$ for $1 \mathrm{~min}$, annealing at $56^{\circ} \mathrm{C}$ for $1 \mathrm{~min}$, extension at $72^{\circ} \mathrm{C}$ for $30 \mathrm{sec}$, and a final extension at $72^{\circ} \mathrm{C}$ for $7 \mathrm{~min}$ to allow for extension of any incomplete products. The PCR product were observed and resolved on agarose gel electrophoresis and visualized under UV-transilluminator by using a Bio-Rad Gel Doc (ChemiDoc ${ }^{\mathrm{TM}} \mathrm{XRS}+$ ) system. The PCR amplicon was purified by using commercial gel extraction kit (Promega Corporation, USA). Purified $16 \mathrm{~S}$ rDNA genes of the two stains were subjected to sequencing separately by Sanger method through the courtesy of Eurofins Genomics India Pvt Ltd., Bangalore, India. The DNA sequencing reaction of PCR amplicon was carried out using BDT v3.1 Cycle sequencing kit on ABI $3730 \times 1$ Genetic Analyzer. Consensus sequence of $16 \mathrm{~S}$ rDNA gene was generated from forward and reverse sequence data using aligner software.

\subsubsection{Construction of Phylogenetic Tree}

The 16S rRNA gene sequences of the two strains RCS252 and RCS260 were aligned separately with the nucleotide sequences of Streptomyces and related genera in GenBank database using BLAST [44]. Sequences with more than 98\% homology were taken for the analysis. Multiple alignments of 16S rRNA nucleotide sequences of the strains RCS252 and RCS260 and sequences from GenBank database were performed separately with CLUSTAL W program [45]. Phylogenetic trees of both the strains were generated separately using neighbor-joining method [46] with bootstrap testing [47] of 1000 replicates, in MEGA6 [48].

\subsection{Statistical Analysis}

It is significant that all the experiments were performed in triplicates and average values were considered. All data were studied and analysed by using Microsoft Office Excel and also to draw the figures.

\section{Results and Discussion}

\subsection{Isolation of Actinomycetes}

The soil sample collected from Domang, in Lachung, North Sikkim, Sikkim, India was used for isolation of actinomycetes. The average soil temperature and relative humidity were found to be $12.21^{\circ} \mathrm{C} \pm 0.24^{\circ} \mathrm{C}$ and $52.07 \%$ respectively in October at the time of sample collection. The soil sample was found to have moisture content of $61.07 \%$ and $\mathrm{pH}$ of 5.65. Four media such as SCA, CSPY-ME, SA and AIA were used for the isolation. A total of 59 actinomycete isolates were 
obtained from the soil sample. Out of the four media used, AIA was found to be most suitable medium for the isolation of actinomycetes as 36 colonies of actinomycetes were observed in this medium, followed by CSPY-ME agar medium with 10 colonies, while 8 and 5 colonies were observed in SA and SCA medium respectively as shown in Figure 2. From the total isolates, 26 isolates having unique and distinct morphological features were selected and analysed for antimicrobial activity as well as production of extracellular industrially important enzymes. Pure cultures were maintained in the same medium that was used for isolation and store at $4^{\circ} \mathrm{C}$. The isolates were also stored at $-80^{\circ} \mathrm{C}$ using glycerol buffer solution in sterile cryo-vials for long term preservation. Our finding highlighting the suitability of AIA for isolation of actinomycetes is also in conformity with the reports by Maiti and Mandal [49] wherein more numbers of actinomycetes were isolated using AIA medium. Similar findings of isolation of actinomycetes using AIA medium was reported by Ganesan et al. [50].

\subsection{Morphological and Cultural Characteristics of the Actinomycetes}

The cultural characteristic features of the actinomycete isolates were observed and noted down with respect to colour, substrate and aerial mycelium, diffusible pigments, colony texture. The results are provided in Table 1. Figure 3 shows cultural morphology of some of the isolates in agar plates as well as the microscopic observation by phase contrast microscopy after growing by cover slip culture.

A per the observation by phase contrast microscopy the spore bearing hyphae and the types of spores arrangement have been note down. Spore chains can be divided morphologically based on length and number of spore [51] and has been noted down in Table 1. Most of the isolates were found to belong to the rectiflexibiles type of spore arrangements, followed by retinaculiaperti type, which

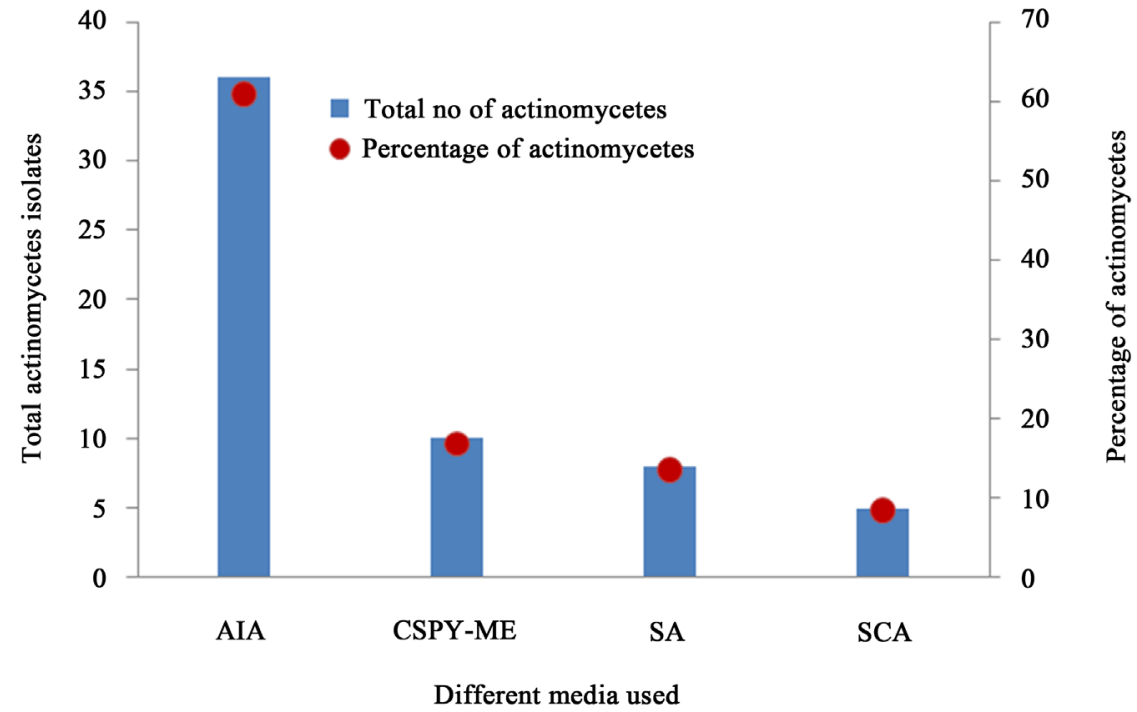

Figure 2. Different nutrient media used for isolation of actinomycetes. 
Table 1. Cultural and colony characteristics of actinomycete isolates from soil of Domang, Lachung, North Sikkim.

\begin{tabular}{|c|c|c|c|c|c|c|}
\hline Isolates & $\begin{array}{l}\text { Colony } \\
\text { texture }\end{array}$ & Substrate mycelium & Aerial mycelium & $\begin{array}{l}\text { Soluble pigment } \\
\text { in medium }\end{array}$ & $\begin{array}{c}\text { Diffusible } \\
\text { pigment in medium }\end{array}$ & $\begin{array}{c}\text { Types } \\
\text { of spore arrangement }\end{array}$ \\
\hline RCS244 & Dry, hard & Brown & Light grey & Brown & Blackish & Monosporous \\
\hline RCS245 & Dry powdery & Brown & White & Brown & Black & Disporous \\
\hline RCS246 & Dry shiny & Light brown & Dark grey & Light brown & No & Rectiflexibiles \\
\hline RCS247 & Powdery & Light grey & White & Light brown & No & Rectiflexibiles \\
\hline RCS248 & Dry & Light brown & White & Light brown & No & Rectiflexibiles \\
\hline RCS249 & Dry shiny & Brown & Whitish & Brown & Black & Rectiflexibiles \\
\hline RCS250 & Powdery & Light grey & Off white & Black & No & Rectiflexibiles \\
\hline RCS251 & Dry & Cream & Light brown & No & No & Retinaculiaperti \\
\hline RCS252 & Dry & Yellowish & Brown & No & Light brown & Long spore chain \\
\hline RCS253 & Powdery & Light grey & Off white & Black & No & Retinaculiaperti \\
\hline RCS254 & Dry & Pink & Cream & Brown & No & Rectiflexibiles \\
\hline RCS255 & Powdery & Dark grey & Grey & Brown & Light brown & Retinaculiaperti \\
\hline RCS256 & Dry, hard & Black & Grey & Dark brown & No & Retinaculiaperti \\
\hline RCS257 & Creamy & Yellow & Off white & Yellowish & No & Fragmenting branched mycelia \\
\hline RCS258 & Powdery & Dark grey & Grey & No & No & Rectiflexibiles \\
\hline RCS259 & Powdery & Dark grey & Grey & No & No & Rectiflexibiles \\
\hline RCS260 & Powdery & Grey & Whitish & Light grey & No & Rectiflexibiles \\
\hline RCS261 & Dry & Grey & Off white & Greyish & No & Fragmenting branched mycelia \\
\hline RCS262 & Powdery & Grey & Light Brown & No & No & Rectiflexibiles \\
\hline RCS263 & Powdery & Grey & Off White & Light brown & No & Rectiflexibiles \\
\hline RCS264 & Dry shiny & Grey & Light Grey & Purple & Purple & Fragmenting branched mycelia \\
\hline RCS265 & Dry & Grey & Off white & No & No & Retinaculiaperti \\
\hline RCS266 & Cottony & Brown & White & Light brown & No & Long spore chain \\
\hline RCS273 & Powdery & Brown & Grey & Light brown & No & Spira \\
\hline RCS274 & Dry shiny & Light brown & Cream & Light black & No & Monosporous \\
\hline RCS276 & Dry & Light brown & Cream & No & No & Monosporous \\
\hline
\end{tabular}

are the characteristic features of Streptomycetes. This reveals that most of the isolates belong to Streptomyces genus. These features of Streptomyces have also been reported by Shirling and Gottlieb [37]. The colour of the substrate mycelia, aerial mycelia, production of soluble pigments, spore arrangements provide important references in the determination of actinomycetes classification. Few isolates have exhibited production of diffusible pigments in the medium as shown in the Figure 3(I). 


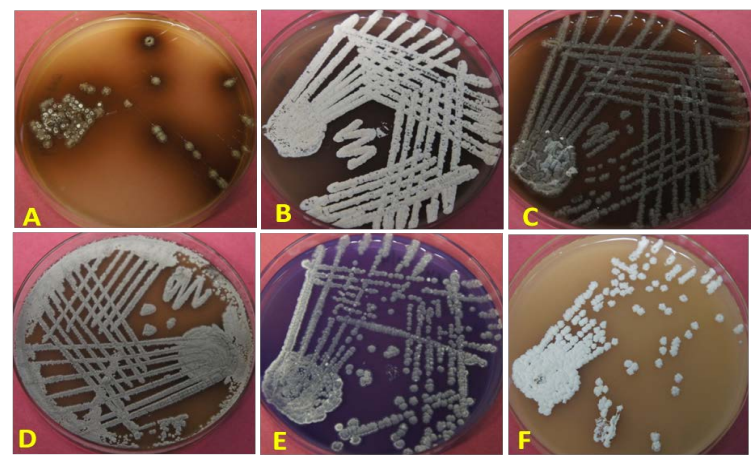

(I)
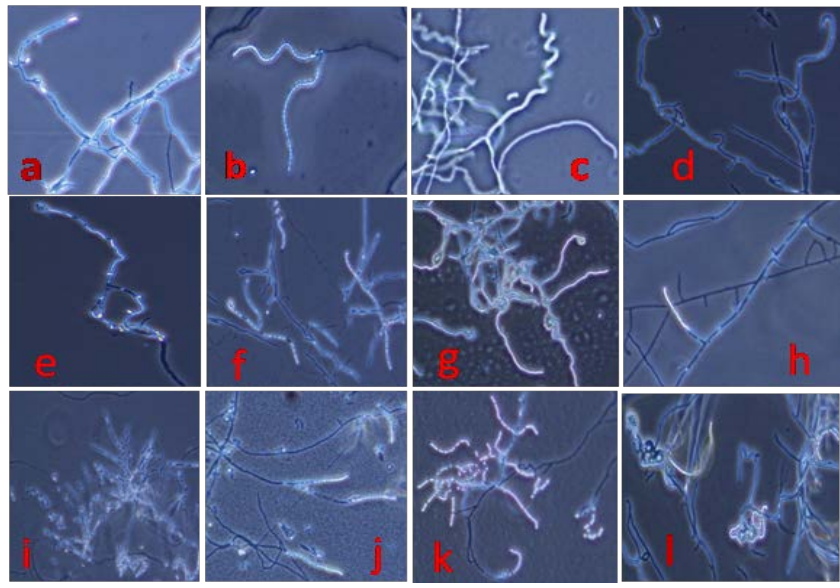

(II)

Figure 3. Morphological features of some of the isolates: (I) Actinomycete isolates [(A) RCS244; (B) RCS245; (C) RCS249; (D) RCS255; (E) RCS264 \& (F) RCS266)] in agar plates (II). Microscopic observation by phase contrast microscopy showing the spore and mycelia of some isolates at $1000 \times$ magnification $(10 \times 100)$ [(a) RCS244; (b) RCS246; (c) RCS247; (d) RCS251; (e) RCS252; (f) RCS253; (g) RCS255; (h) RCS258; (i) RCS260; (j) RCS263; (k) RCS266; (l) RCS273].

\subsection{Antimicrobial Activity of the Isolates}

All the 26 selected actinomycete isolates were evaluated for antimicrobial potentiality against fungal phytopathogens and bacteria. Out of 26 isolates, 17 (66\%) isolates were found to exhibit different level of growth inhibition against the test microorganism. Table 2 shows the antimicrobial activity of only the active isolates. $12(47 \%)$ isolates showed antifungal activity and six (23\%) isolates showed antibacterial activity. Most of the isolates exhibited antifungal activity. Isolate RCS260 was found to exhibit maximum growth inhibition (60\%) against $C$. gloeosporioides MTCC 8021 followed by isolates RCS263 and RCS246 which showed 57\% growth inhibition against $C$. gloeosporioides MTCC 8021 and $C$. gloeosporioides ITCC 5514 respectively. Isolate RCS252 showed maximum growth inhibition (67\%) against B. subtilis MTCC 441 followed by RCS253 and RCS251. Figure 4(A) showed the in-vitro antagonistic activity of RCS260 against $C$. gloeosporioides MTCC 8021 and C. capsici MTCC 3414 while Figure 4(B) showed the antibacterial activity of RCS252 against B. subtilis MTCC 441 
Table 2. Antimicrobial activity of active actinomycete isolates against test microorganisms expressed as percentage.

\begin{tabular}{|c|c|c|c|c|c|c|}
\hline Isolate no. & $\begin{array}{l}\text { C. gloeosporioides } \\
\text { MTCC } 8021\end{array}$ & $\begin{array}{l}\text { C. gloeosporioides } \\
\text { ITCC } 5514\end{array}$ & $\begin{array}{c}\text { C. capsici } \\
\text { MTCC } 3414\end{array}$ & $\begin{array}{l}\text { C. acutatum } \\
\text { MTCC } 2213\end{array}$ & $\begin{array}{c}\text { E. coli } \\
\text { MTCC } 739\end{array}$ & $\begin{array}{l}\text { B. subtilis } \\
\text { MTCC } 441\end{array}$ \\
\hline RCS246 & 55 & 57 & 38 & 43 & $-\mathrm{ve}$ & $-\mathrm{ve}$ \\
\hline RCS247 & 35 & 19 & 10 & - ve & - ve & - ve \\
\hline RCS249 & 25 & 15 & $-\mathrm{ve}$ & -ve & $-\mathrm{ve}$ & $-\mathrm{ve}$ \\
\hline RCS250 & 31 & 20 & $-\mathrm{ve}$ & $-\mathrm{ve}$ & $-\mathrm{ve}$ & $-\mathrm{ve}$ \\
\hline RCS251 & 32 & 25 & - ve & 10 & - ve & 35 \\
\hline RCS252 & - ve & $-\mathrm{ve}$ & $-\mathrm{ve}$ & $-\mathrm{ve}$ & 24 & 67 \\
\hline RCS253 & $-\mathrm{ve}$ & $-\mathrm{ve}$ & $-\mathrm{ve}$ & $-\mathrm{ve}$ & - ve & 36 \\
\hline RCS255 & 47 & 30 & 25 & 33 & $-\mathrm{ve}$ & $-\mathrm{ve}$ \\
\hline RCS258 & 46 & 28 & 23 & 31 & $-\mathrm{ve}$ & 24 \\
\hline RCS260 & 60 & 55 & 50 & 45 & $-\mathrm{ve}$ & $-\mathrm{ve}$ \\
\hline RCS262 & - ve & $-\mathrm{ve}$ & $-\mathrm{ve}$ & - ve & - ve & 35 \\
\hline RCS263 & 57 & 53 & 40 & 41 & - ve & $-\mathrm{ve}$ \\
\hline RCS265 & 51 & 48 & 35 & 41 & $-\mathrm{ve}$ & $-\mathrm{ve}$ \\
\hline RCS266 & 36 & 21 & 11 & 23 & $-\mathrm{ve}$ & - ve \\
\hline RCS273 & 44 & 24 & 19 & 30 & - ve & $-\mathrm{ve}$ \\
\hline RCS274 & $-\mathrm{ve}$ & $-\mathrm{ve}$ & $-\mathrm{ve}$ & $-\mathrm{ve}$ & $-\mathrm{ve}$ & $-\mathrm{ve}$ \\
\hline RCS276 & - ve & - ve & - ve & $-\mathrm{ve}$ & - ve & 6 \\
\hline
\end{tabular}

Note: Numericals indicate Percentage Growth Inhibition; -ve = No growth Inhibition.
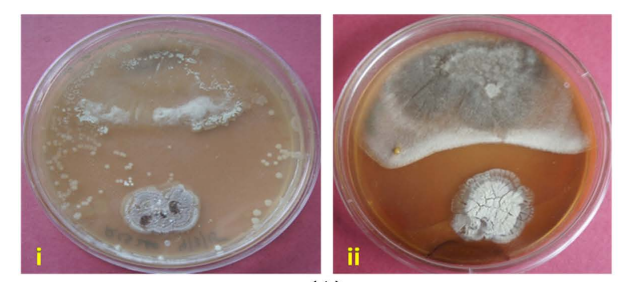

(A)
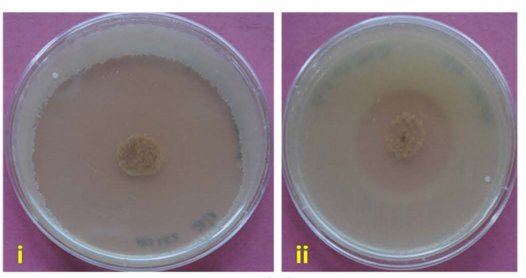

(B)

Figure 4. (A) In-vitro antagonistic activity of RCS260 against (i) C. gloeosporioides MTCC 8021 (ii) C. capsici MTCC 3414; (B) Antibacterial activity exhibited by RCS252 against (i) B. subtilis MTCC 441 (ii) E. coli MTCC 739.

and E. coli MTCC 739. The results signify that the isolates grown on agar plates produced extracellular diffusible metabolites (s) which inhibited the hyphae growth of the fungal pathogens. Similarly the diffusible metabolites produce in the agar plates brought about the growth inhibition of the bacterial test pathogens in the of agar overlaying assay. Similar findings of actinomycetes exhibiting antimicrobial activity in solid medium have been reported by Singh et al. [14]. Prapagdee et al. [31] reported the strong inhibition of fungal phytopathogen including $C$. gloeosporioides by $S$. hygroscopicus due to production of extracellular metabolites. Antagonistic potential of actinomycetes against phytopathogenic fungi were brought about due to the production of extracellular hydrolytic en- 
zymes as well as secondary metabolites [52] [53] [54]. Potential isolates such as RCS252 and RCS260 which showed maximum activity were taken for further identification up to species level.

\subsection{Production of Extracellular Enzyme by the Isolates}

All the 26 isolates were tested qualitatively for production of extracellular enzymes such as chitinase, cellulase, amylase and protease in solid agar medium. Out of 26 isolates, 14 (54\%) isolates showed positive for chitinase activity, 25 (96\%) isolates tested positive for cellulase production, 20 (77\%) isolates were found to produce amylase enzyme and 17 (65\%) isolates showed positive for protease activity as shown in Figure 5. The qualitative assay for the enzyme activity of some of the isolates is shown in Figure 6. It was also observed that all the isolates produced at least one of the enzymes.

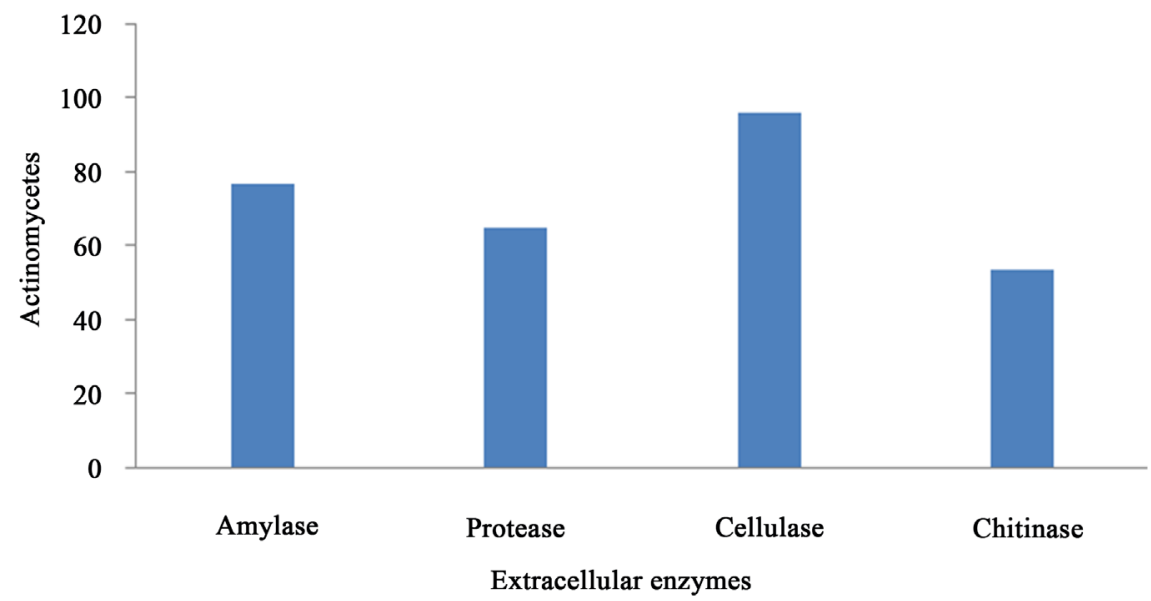

Figure 5. Actinomycete isolates showing production of different extracellular enzymes.

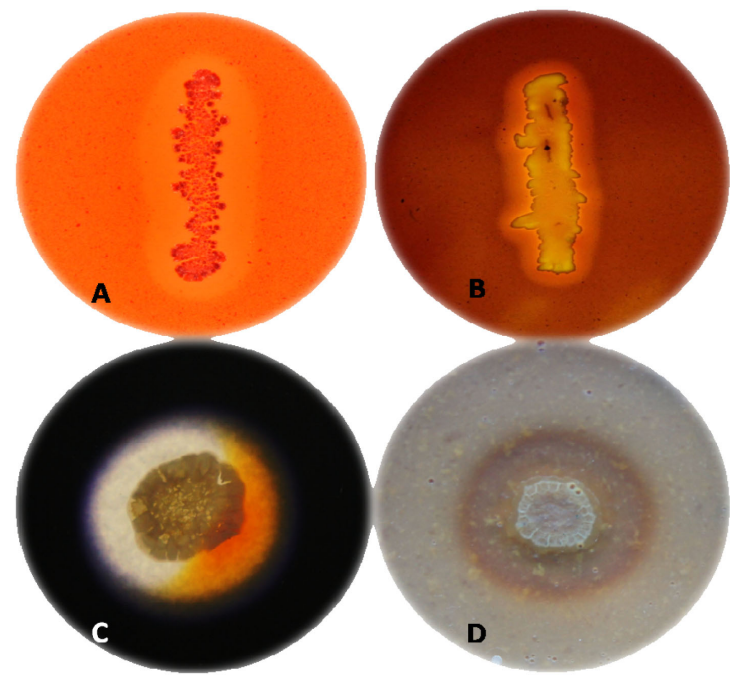

Figure 6. Screening for extracellular enzyme production by actinomycete isolates (A) Chitinase activity of RCS248 (B) Cellulase activity of RCS260 (C) Amylase activity of RCS260 and (D) Protease activity of RCS252. 
Positive chitinase activity was assayed by observing the characteristic clear zone around the colony. Isolate RCS248 was found to exhibit notable chitinase activity as evident from the zone of clearance. The formation of clear zone was virtually due to the degradation of chitin in the growing medium. The larger zone formation indicates greater activity. Not all isolates provide good results. Isolates which does not produce clear zone might be because of the rate of reaction that did not hydrolyzed chitin well. Chitinase degrade chitin into monomers and brings about inhibiting the growth of fungal pathogens. The appearance of clear zone around the colony, caused the termination of the $\beta-1,4 \mathrm{~N}$-acetylglucosamine bond by chitinase into monomer GlcNAc. More the number of monomer GlcNAc is produced; the larger clear zone was formed around the colonies. Addition of Congo red dye in the medium make the visibility of clear zone better. Positively charged Congo red detects the nonpolar hydrogen bonding in carbohydrates resulting in orange red color, whereas clear zone formed due to the reduction of chitin remains clear. Cellulase activity was observed in medium containing CMC. Formation of clear zone around the colonies after staining with Gram's iodine indicates production of cellulase by the isolates. Isolate RCS260 was found to exhibit significant cellulase activity as indicated from the zone of clearance. The isolates utilized cellulose from the medium. Qualitative screening for extracellular cellulase production by microorganisms is often carried out on agar medium containing CMC as substrate [55]. The method is easier as the results are obtained directly and quickly. In our study the actinomycete isolates bring about the hydrolytic activity on carboxymethyl cellulose due the production of enzyme cellulase in the medium. Amylase production by the isolates was detected on starch agar medium. The formation of clear zone around the colonies indicates positive for amylase activity by the isolates. The isolates displayed various zone of clearance. Isolate RCS260 displayed noteworthy amylase activity. Similar analysis of amylase production on starch agar has been carried out. Notable amylase production by S. gulbargensis DAS 131 and $S$. avermitilis have been reported [56] [57]. Amylase is one of the most significant industrial enzymes. Huge quantity of amylase is being used every year in the various industrial applications. Amylase finds various applications in food industry, fermentation, textile and paper industries and there is huge demand on a global market [58] [59]. Amylases are produce from various sources however microbial sources are the most preferred one for large scale production and have found successful applications in starch saccharification, brewing as well as distilling industries [60]. The proteolytic activity of the isolates was detected using skim milk agar. Formation of clear zone around the colonies indicated positive for the extracellular protease production in the medium by the isolates. The hydrolysis of casein in the medium due to the release of enzyme results in the development of zone around the colony. Isolate RCS252 was found to exhibit significant proteolytic activity. Production of protease by actinomycetes has been reported by Jeyadharsan [35]. 


\subsection{Siderophores Production}

Siderophores productions by the isolates were screened by chrome azurol S method. The isolates which produced siderophores were detected as the presence of iron chelator siderophores was indicated by decolourization of a blue coloured medium containing ferric CAS complex into yellow halo zone around the colonies. Out of 26 isolates screened, 19 (73\%) isolates showed the production of siderophores in agar medium. Isolate RCS265 exhibited noteworthy siderophores production as evident from the yellow halo around the colony which is shown in Figure 7. Siderophores production by Streptomyces sp. MT7 has been reported by Nagpure et al. [24]. Chelation of $\mathrm{Fe}^{3+}$ by siderophores results in unavailability of iron to the phytopathogens. It has often been assumed that competition for $\mathrm{Fe}$ in the rhizosphere is controlled by the Fe affinity of the siderophores, whereby the ligands produced by the biocontrol agent have higher formation constants than those of the pathogen [36].

\subsection{Identification and Characterization of the Potential Strains}

The two potential isolates RCS260 and RCS252 have been characterized and identified. Both the strains are Gram-positive filamentous actinobacteria. The morphological, physiological and biochemical characteristics of the two strains is shown in Table 3. The substrate mycelium of strain RCS260 showed grey colour while the aerial mycelium showed whitish colour. The strain does not produce any diffusible pigments in the medium. The culture, when observed by phase contrast microscopy reveals rectiflexibiles type of sporophores arising from the aerial mycelium and may be placed in the Rectus-Flexibilis (RF) group of Streptomyces species [61]. LL-diaminopimelic acid (L-DAP) was present in the cell wall of strain RCS260 but no characteristic sugar. The 16S rRNA gene sequence of the strain RCS260 was compared with the nucleotide sequences of other Streptomyces strains from the NCBI GenBank database. The phylogenetic tree generated on the basis of 16S rRNA gene sequence of the strain RCS260 and the

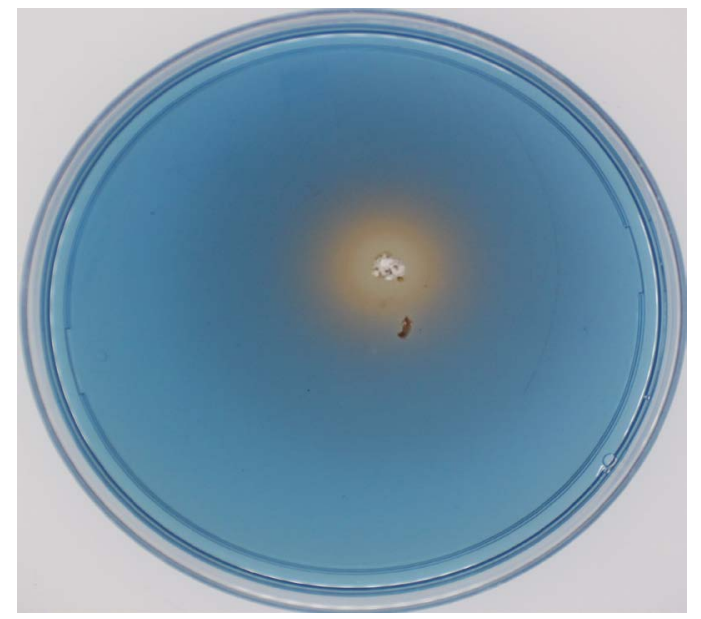

Figure 7. Actinomycete isolate RCS265 exhibiting siderophores production indicated by the yellow halo around the colony. 
Table 3. Morphological, physiological and biochemical characteristics of strain RCS252 and RCS260.

\begin{tabular}{|c|c|c|}
\hline \multirow[b]{2}{*}{ Property } & \multicolumn{2}{|c|}{ Result } \\
\hline & $\begin{array}{c}\text { Kitasatospora } \\
\text { aburaviensis strain } \\
\text { RCS252 }\end{array}$ & $\begin{array}{c}\text { Streptomyces } \\
\text { vinaceus } \text { strain } \\
\text { RCS } 260\end{array}$ \\
\hline \multicolumn{3}{|l|}{ Morphological characteristics } \\
\hline Cell shape & Mycelial & Mycelial \\
\hline Sporophore morphology & Long spore chain & Rectus-Flexibilis (RF) \\
\hline Aerial mycelium colour & Brown & Whitish \\
\hline Substrate mycelium colour & Yellowish & Grey \\
\hline \multicolumn{3}{|l|}{ Physiological characteristics } \\
\hline Growth under anaerobic condition & $-\mathrm{ve}$ & $-\mathrm{ve}$ \\
\hline Acid-fast reaction & $-\mathrm{ve}$ & $-\mathrm{ve}$ \\
\hline Temperature range for growth & $25^{\circ} \mathrm{C}-40^{\circ} \mathrm{C}$ & $25^{\circ} \mathrm{C}-40^{\circ} \mathrm{C}$ \\
\hline Optimum temperature for growth & $28^{\circ} \mathrm{C}$ & $28^{\circ} \mathrm{C}$ \\
\hline $\mathrm{pH}$ range for growth & $5-8$ & $5-8$ \\
\hline Optimum $\mathrm{pH}$ for growth & 7 & 7 \\
\hline Growth on Mc Conkey agar & $-\mathrm{ve}$ & $-\mathrm{ve}$ \\
\hline $\mathrm{NaCl}$ tolerance & $3 \%$ & $4 \%$ \\
\hline \multicolumn{3}{|l|}{ Biochemical characteristics } \\
\hline Gram reaction & +ve & $+\mathrm{ve}$ \\
\hline Catalase production & $-\mathrm{ve}$ & $-\mathrm{ve}$ \\
\hline Oxidase production & $-\mathrm{ve}$ & -ve \\
\hline Urease production & $-\mathrm{ve}$ & $-\mathrm{ve}$ \\
\hline Hydrogen sulfide production & $-\mathrm{ve}$ & $-\mathrm{ve}$ \\
\hline Nitrate reduction & $-\mathrm{ve}$ & $-\mathrm{ve}$ \\
\hline Gelatin liquefaction & +ve & $+\mathrm{ve}$ \\
\hline Methyl red test & -ve & -ve \\
\hline Vogues proskauer test & $-\mathrm{ve}$ & $-\mathrm{ve}$ \\
\hline Indole production test & $-\mathrm{ve}$ & $-\mathrm{ve}$ \\
\hline Citrate utilization test & -ve & -ve \\
\hline Starch hydrolysis & +ve & $+\mathrm{ve}$ \\
\hline Casein hydrolysis & +ve & $+\mathrm{ve}$ \\
\hline \multicolumn{3}{|l|}{ Acid production from } \\
\hline Glucose & -ve & -ve \\
\hline Arabinose & $-\mathrm{ve}$ & $-\mathrm{ve}$ \\
\hline Mannitol & $-\mathrm{ve}$ & $-\mathrm{ve}$ \\
\hline Xylose & $-\mathrm{ve}$ & $-\mathrm{ve}$ \\
\hline Meso-inositol & $-\mathrm{ve}$ & $-\mathrm{ve}$ \\
\hline Sucrose & $-\mathrm{ve}$ & $-\mathrm{ve}$ \\
\hline Galactose & -ve & $-\mathrm{ve}$ \\
\hline Fructose & $-\mathrm{ve}$ & $-\mathrm{ve}$ \\
\hline Cell-wall amino acids & $\begin{array}{l}\text { Both LL-Diaminopimelic } \\
\text { acid and mes-DAP }\end{array}$ & LL-Diaminopimelic acid \\
\hline
\end{tabular}


nucleotide sequences from closely related Streptomyces strains using neighbor-joining method is presented in Figure 8. The strain has got highest $16 \mathrm{~S}$ rRNA gene sequence similarity with $S$. vinaceus strain AS-65. Hence, on the basis of morphological, physiological, biochemical and analysis of the $16 \mathrm{~S}$ rRNA gene sequence, the new isolate RCS260 has been identified and designated as $S$. vinaceus strain RCS260. 16S rRNA gene partial sequence of the isolate RCS260 has been deposited in the GenBank database under the accession number MK942687.

The substrate mycelium of strain RCS252 showed yellowish colour while the aerial mycelium showed brown colour. The strain produces light brown diffusible pigments in the medium. The culture exhibited long chain of spores arising from the aerial mycelium. Both LL-diaminopimelic acid (L-DAP) and meso-DAP was observed in the cell wall of strain RCS252. Presence of both L-DAP and meso-DAP is the characteristic features of the genus Kitasatospora as reported by Takahashi [62]. The 16S rRNA gene sequence of the strain RCS252 was compared with the nucleotide sequences of other Kitasatospora and Streptomyces strains from the NCBI GenBank database. Similarly the phylogenetic tree was generated based on the 16S rRNA gene sequence of the strain RCS252 and the nucleotide sequences from closely related strains using neighbor-joining method as shown in Figure 9. The strain RCS252 has got highest 16S rRNA gene sequence similarity with $K$. aburaviensis strain CSSP531. Thus on the basis of different characteristic features and analysis of the 16S rRNA gene sequence, the new isolate RCS252 has been identified and designated as $K$. aburaviensis strain RCS252. 16S rRNA gene partial sequence of the strain has been deposited in the NCBI GenBank database under the accession number MK942686.

The results of the present invetigation indicate that the antagonistic activities of the selected actinomycete isolates against the fungal test pathogen could be the result of production of chitinase, cellulase, protease along with other antimicrobial metabolites. Some of the actinomycete strains are also able to inhibit the

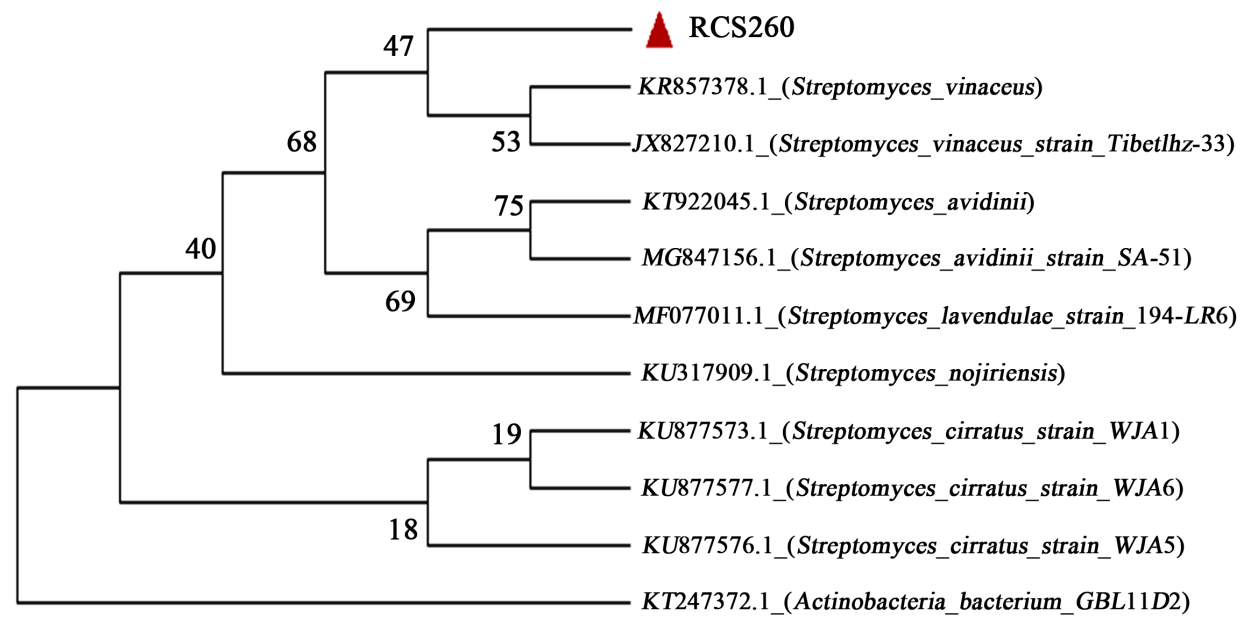

Figure 8. Phylogenetic tree based on 16S rRNA gene sequences from Streptomyces vinaceus strain RCS260 with other closely related Streptomyces species. 


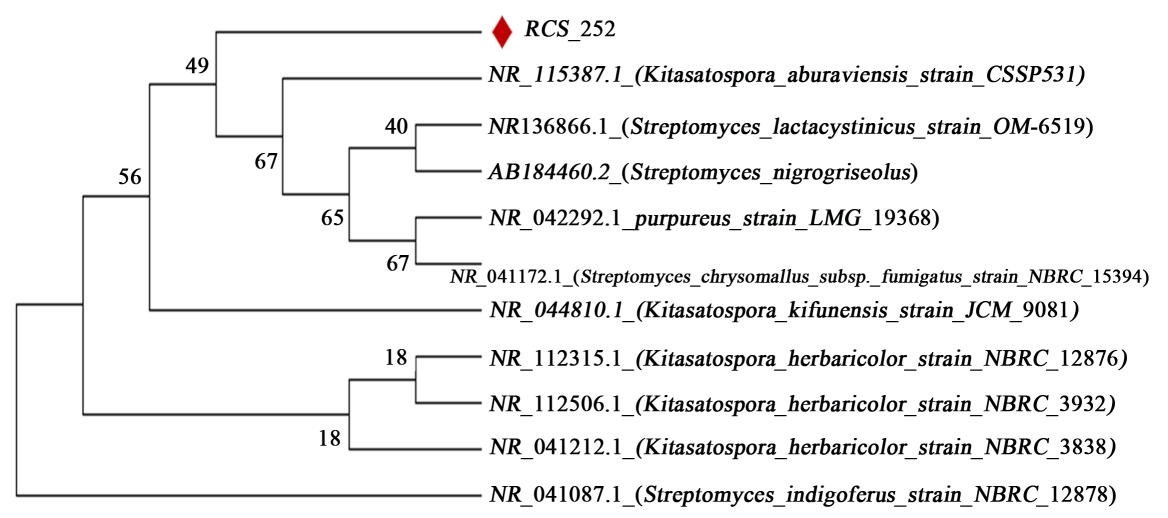

Figure 9. Phylogenetic tree based on 16S rRNA gene sequences from Kitasatospora aburaviensis strain RCS252 with other closely related species.

growth of gram positive and gram negative bacterial test pathogen with less activity against the gram negative pathogen. The antifungal activity of antagonists has been attributed to the action of hydrolytic enzymes including chitinase, alpha 1, 3-glucanase, chitosanase as well as protease [63] [64]. Therefore the production of extracellular chitinase and cellulase by the isolates in our study has significant relevance since most of the isolates which produce these enzymes also exhibited antifungal activity. It has been reported that the production of chitinase and alpha 1,3-glucanase enzymes by Streptomyces was related to fungal growth inhibition and the biological control of fungal pathogens was possible because of the ability of Streptomyces to degrade fungal cell walls [52] [63]. Microbial products as biological control agents are being examined as alternatives to synthetic chemicals in agriculture. Sikkim is one of the largest producers of large cardamom (Amomum subulatum Roxb.), which is also a major source of income for the farmers of this tiny Himalayan state. There has been a significant decline in the yield of large cardamom over the years. Among many factors for the decline, fungal blight of large cardamom cause by $C$. gloeosporioides is a major concern [65]. So far there is no effective control measure for this devastating disease of large cardamom. Sikkim being declared as organic state, natural products from microbial sources could be used as an alternative to chemical pesticides. Our study holds relevance in this aspect since most of actinomycete isolates screened exhibits noteworthy antifungal activity against the C. gloeosporioides. Many commercially important bioactive compounds, antibiotics, other bio agents have been discovered from actinomycetes isolated from pristine regions. Streptomyces sp. MT7 obtained from Manipur has been reported to exhibit antagonistic efficiency against fungal pathogen [24] Antifungal activity of a polyene metabolite obtained from Streptomyces sp. isolated from Kodachadri region of Western Ghats has been reported by Shobha and Onkarappa [66]. Thakur et al. [67] reported the isolation of Streptomyces sp. from soil samples collected from the forest of Assam and Tripura highlighting broad spectrum antifungal and antibacterial activity. Bharti et al. [68] reported the dominant antifungal nature of Streptomyces sp. compared to other genera of actinomycetes, 
isolated from unexplored Garhwal region. Consequently, the taxonomic diversity even within the well-studied group of terrestrial actinomycetes is likely to be far from exhausted.

\section{Conclusion}

The present investigation outlined the potential of actinomycetes isolated from rhizosphere soil from Lachung, North Sikkim, India exhibiting antimicrobial activity. Out of the total isolates, 17 (66\%) isolates showed antimicrobial activity and almost all the isolates produce at least one extracellular enzyme. The antifungal spectrum of antagonistic activity exhibited by the potential isolate RCS260 against the phytopathogens further testifies the prospective of the unexplored actinomycetes from this region. This screening highlights the potential of the strain RCS260 as a candidate towards the search of antifungal agent to mitigate the burden of phytopathogens causing crop losses. This result throws light on the merit for further study of the potential strain. Further studies on the extraction, analysis of the nature of the metabolite will be carried out to establish and confirm the importance of the isolate from this pristine ecological niche.

\section{Acknowledgements}

The authors thank the Department of Biotechnology (DBT), Government of India, New Delhi for the financial assistance. We are very grateful to anonymous reviewers and the editor for their kind comments and suggestions to improve this manuscript.

\section{Authors' Contribution}

LSS: performed the entire experiment and prepared the manuscript. HS: assisted LSS in conducting the experiment and also in preparing the manuscript. DS: Coordinated the study. All authors have duly checked and approved the manuscript before submission.

\section{Conflicts of Interest}

The authors declare that there are no conflicts of interests.

\section{References}

[1] Goshi, K., Uchida, T., Lezhava, A., Yamasaki, M., Hiratsu, K., Shinkawa, H. and Kinashi, H. (2002) Cloning and Analysis of the Telomere and Terminal Inverted Repeat of the Linear Chromosome of Streptomyces griseus. Journal of Bacteriology, 184, 3411-3415. https://doi.org/10.1128/JB.184.12.3411-3415.2002

[2] Schaal, K.P. and Lee, H.J. (1992) Actinomycete Infections in Humans-A Review. Gene, 115, 201-211. https://doi.org/10.1016/0378-1119(92)90560-C

[3] Benson, D.R. and Silvester, W.B. (1993) Biology of Frankia Strains, Actinomycete Symbionts of Actinorhizal Plants. Microbiological Reviews, 57, 293-319. https://mmbr.asm.org/content/mmbr/57/2/293.full.pdf

[4] Promnuan, Y., Kudo, T. and Chantawannakul, P. (2009) Actinomycetes Isolated 
from Beehives in Thailand. World Journal of Microbiology and Biotechnology, 25, 1685-1689. https://doi.org/10.1007/s11274-009-0051-1

[5] Bascom-Slack, C.A., Ma, C., Moore E., Babbs, B., Fenn, K., Greene, J.S., Hann, B.D., Keehner, J., Kelley-Swift, E.G., Kembaiyan, V., Lee, S.J., Li, P., Light, D.Y., Lin, E.H., Schorn, M.A., Vekhter, D., Boulanger, L.-A., Hess, W.M., Vargas, P.N., Strobel, G.A. and Strobel, S.A. (2009) Multiple, Novel Biologically Active Endophytic Actinomycetes Isolated from Upper Amazonian Rainforests. Microbial Ecology, 58, 374-383. https://doi.org/10.1007/s00248-009-9494-Z

[6] Mellouli, L., Ameur-Mehdi, R.B., Sioud, S., Salem, M. and Bejar, S. (2003) Isolation, Purification and Partial Characterization of Antibacterial Activities Produced by a Newly Isolated Streptomyces sp. US24 Strain. Research in Microbiology, 154, 345-352. https://doi.org/10.1016/S0923-2508(03)00077-9

[7] Vezina, C., Kudelski, A and Sehgal, S.N. (1975) Rapamycin (AY-22,989), a New Antifungal Antibiotic. I. Taxonomy of the Producing Streptomycete and Isolation of the Active Principle. Journal of Antibiotics, 28, 721-726.

https://www.ncbi.nlm.nih.gov/pubmed/1102508

[8] Mohamed, H.S. and Galal, A.M. (2005) Identification and Antiviral Activities of Some Halotolerant Streptomycetes Isolated from Qaroon Lake. International Journal of Agriculture and Biology, 7, 747-753.

https://www.researchgate.net/publication/237304458

[9] Mao, Y., Varoglu, M. and Sherman, D.H. (1999) Molecular Characterization and Analysis of the Biosynthetic Gene Cluster for the Antitumor Antibiotic Mitomycin C from Streptomyces lavendulae NRRL 2564. Chemistry and Biology, 6, 251-263. https://doi.org/10.1016/S1074-5521(99)80040-4

[10] Barbosa-Filh, J.M., Martins, V.K.M., Rabelo, L.A., Moura, M.D., Silva, M.S., Cunha, E.V.L., Souza, M.F.V., Almeida, R.N. and Madeiros, I.A. (2006) Natural Products Inhibitors of the Angiotensin Converting Enzyme (ACE). A Review between 1980-2000. Revista Brasileira de Farmacognosia, 16, 421-446. https://doi.org/10.1590/S0102-695X2006000300021

[11] Pahl, A. and Keller, U. (1992) FK-506-Binding Proteins from Streptomycetes Producing Immunosuppressive Macrolactones of the FK-506 Type. Journal of Bacteriology, 174, 5888-5894. https://jb.asm.org/content/174/18/5888.short https://doi.org/10.1128/jb.174.18.5888-5894.1992

[12] Doumbou, C.L., Salove, M.K.H., Crawford, D.L. and Beaulieu, C. (2002) Actinomycetes, Promising Tools to Control Plant Diseases and to Promote Plant Growth. Phytoprotection, 82, 85-102. https://doi.org/10.7202/706219ar

[13] Berdy, J. (2005) Bioactive Microbial Metabolites. The Journal of Antibiotics, 58, 1-26. https://doi.org/10.1038/ja.2005.1

[14] Singh, L.S., Baruah, I. and Bora, T.C. (2006) Actinomycetes of Loktak Habitat: Isolation and Screening for Antimicrobial Activities. Biotechnology, 5, 217-221. https://doi.org/10.3923/biotech.2006.217.221

[15] Singh, L.S., Mazumder, S. and Bora, T.C. (2009) Optimisation of Process Parameters for Growth and Bioactive Metabolite Produced by a Salt-Tolerant and Alkaliphilic Actinomycete, Streptomyces tanashiensis Strain A2D. Journal de Mycologie Médicale, 19, 225-233. http://www.sciencedirect.com/science/journal/11565233 https://doi.org/10.1016/j.mycmed.2009.07.006

[16] Singh, L.S., Sharma, H. and Talukdar, N.C. (2014) Production of Potent Antimicrobial Agent by Actinomycete, Streptomyces sannanensis Strain SU118 Isolated from Phoomdi in Loktak Lake of Manipur, India. BMC Microbiology, 14, 278. 
https://doi.org/10.1186/s12866-014-0278-3

[17] Adhi, T.P., Korus, R.A. and Crawford, D.L. (1989) Production of Major Extracellular Enzymes during Lignocellulose Degradation by Two Streptomycetes in Agitated Submerged Culture. Applied and Environmental Microbiology, 55, 1165-1168. https://core.ac.uk/display/3271733

[18] Godden, B., Legon, T., Helvenstein, P. and Penninckx, M. (1989) Regulation of the Production of Hemicellulolytic and Cellulolytic Enzymes by a Streptomyces sp. Growing on Lignocellulose. Journal of General Microbiology, 135, 285-292. https://doi.org/10.1099/00221287-135-2-285

[19] Sun, Y. and Cheng, J. (2002) Hydrolysis of Lignocellulosic Materials for Ethanol Production : A Review. Bioresource Technology, 83, 1-11. https://doi.org/10.1016/S0960-8524(01)00212-7

[20] Pometto, A.L., Lee, B. and Johnson, K.E. (1992) Production of an Extracellular Polyethylene-Degrading Enzyme(s) by Streptomyces Species. Applied and Environmental Microbiology, 58, 731-733. https://aem.asm.org/content/aem/58/2/731.full.pdf

[21] Goodfellow, M. and Williams, S.T. (1983) Ecology of Actinomycetes. Annual Review of Microbiology, 37, 189-216. https://doi.org/10.1146/annurev.mi.37.100183.001201

[22] Mc Carthy, A.J. and Williams, S.T. (1992) Actinomycetes as Agents of Biodegradation in the Environment-A Review. Gene, 115, 189-192. https://doi.org/10.1016/0378-1119(92)90558-7

[23] Itoh, Y., Takahashi, K., Takizawa, H., Nikaidou, N., Tanaka, H., Nishihashi, H., Watanabe, T. and Nishizawa, Y. (2003) Family 19 Chitinase of Streptomyces griseus HUT6037 Increases Plant Resistance to the Fungal Disease. Bioscience, Biotechnology, and Biochemistry, 67, 847-855. https://doi.org/10.1271/bbb.67.847

[24] Nagpure, A., Choudhary, B., Kumar, S. and Gupta, R.K. (2014) Isolation and Characterization of Chitinolytic Streptomyces sp. MT7 and Its Antagonism towards Wood-Rotting Fungi. Annals of Microbiology, 64, 531-541. https://doi.org/10.1007/s13213-013-0686-x

[25] Baltz, R.H. (2005) Antibiotic Discovery from Actinomycetes: Will a Renaissance Follow the Decline and Fall? SIM News, 55, 186-196. https://www.researchgate.net/publication/284626065

[26] Nedialkova, D. and Naidenova, M. (2005) Screening the Antimicrobial Activity of Actinomycetes Strains Isolated from Antarctica. Journal of Culture Collection, 4, 29-35. https://www.researchgate.net/publication/26414809

[27] El-Nakeeb, M.A. and Lechevalier, H.A. (1963) Selective Isolation of Aerobic Actinomycetes. Applied Microbiology, 11, 75-77. https://www.ncbi.nlm.nih.gov/pmc/articles/PMC1057945/

[28] Williams, S.T. and Davies, F.L. (1965) Use of Antibiotics for Selective Isolation and Enumeration of Actinomycetes in Soil. Journal of General Microbiology, 38, 251-261. https://doi.org/10.1099/00221287-38-2-251

[29] Forbes, B.A., Sahm, D.F., Weissfeld, A.S. and Trevino, E.A. (1990) Bailey and Scott's Diagnostic Microbiology. Mosby Co., St. Louis, MO, 171-194.

[30] de Oliveira, M.F., da Silva, M.G. and Van Der Sand, S.T. (2010) Anti-Phytopathogen Potential of Endophytic Actinobacteria Isolated from Tomato plants (Lycopersicon esculentum) in Southern Brazil, and Characterization of Streptomyces sp. R18(6), a Potential Biocontrol Agent. Research in Microbiology, 161, 565-572.

https://doi.org/10.1016/j.resmic.2010.05.008 
[31] Prapagdee, B., Kuekulvong, C. and Mongkolsuk, S. (2008) Antifungal Potential of Etracellular Metabolites Produced by Streptomyces hygroscopicus against Phytopathogenic Fungi. International Journal of Biological Science, 4, 330-337.

https://doi.org/10.7150/ijbs.4.330 http://www.ijbs.com/v04p0330.htm

[32] Zivkovic, S., Stojanovic, S., Ivanovic, Z., Gavrilovic, V., Popovic, T. and Balaz, J. (2010) Screening of Antagonistic Activity of Microorganisms against Colletotrichum acutatum and Colletotrichum gloeosporioides. Archives of Biological Sciences, 62, 611-623. https://doi.org/10.2298/ABS1003611Z

[33] Kasana, R.C., Salwan, R., Dhar, H., Dutt, S. and Gulati, A. (2008) A Rapid and Easy Method for the Detection of Microbial Cellulases on Agar Plates Using Gram's Iodine. Current Microbiology, 57, 503-507. https://doi.org/10.1007/s00284-008-9276-8

[34] Rengasamy, S. and Thangaprakasam, U. (2018) Isolation, Screening and Determination of $\alpha$-Amylase Activity from Marine Streptomyces Species. International Journal of Pharmacy and Pharmaceutical Sciences, 10, 122-127. https://doi.org/10.22159/ijpps.2018v10i4.24447

[35] Jeyadharsan, V.N. (2013) Production and Partial Purification of Protease by Actinomyces Species. International Journal of Scientific and Research Publications, 3, $1-3$.

[36] Beneduzi, A., Peres, D., Vargas, L.K., Bodanese-Zanettini, M.H. and Passaglia, L.M.P. (2008) Evaluation of Genetic Diversity and Plant Growth Promoting Activities of Nitrogen-Fixing Bacilli Isolated from Rice Fields in South Brazil. Applied Soil Ecology, 39, 311-320. https://doi.org/10.1016/j.apsoil.2008.01.006

[37] Shirling, E.B. and Gottlieb, D. (1966) Methods for Characterization of Streptomyces sp. International Journal of Systematic and Evolutionary Microbiology, 16, 313-340. https://doi.org/10.1099/00207713-16-3-313

[38] Locci, R. (1989) Streptomycetes and Related Genera. In: Williams, S.T., Ed., Bergey's Manual of Systematic Bacteriology, Williams and Wilkins Company, Baltimore, MD, 2451-2469.

[39] Pridham, T.G. and Gottlieb, D. (1948) The Utilization of Carbon Compounds by Some Actinomycetales as an Aid for Species Determination. Journal of Bacteriology, 56, 107-114.

[40] Gordon, R.E., Barnett, D.A., Handerhan, J.E. and Pang, C.H. (1974) Nocardia coeliaca, Nocardia autotrophica and the Nocardia Strain. International Journal of Systematic Bacteriology, 24, 54-63. https://doi.org/10.1099/00207713-24-1-54

[41] Becker, B., Lechevalier, M.P., Gordon, R.E. and Lechevalier, H.A. (1964) Rapid Differentiation between Nocardia and Streptomyces by Paper Chromatography of Whole-Cell Hydrolysates. Journal of Applied Microbiology, 12, 421-423.

[42] Lechevalier, M.P. and Lechevalier, H. (1970) Chemical Composition as a Criterion in the Classification of Aerobic Actinomycetes. International Journal of Systematic and Evolutionary Microbiology, 20, 435-443.

https://doi.org/10.1099/00207713-20-4-435

[43] Marmur, J. (1961) A Procedure for the Isolation of Deoxyribonucleic Acid from Micro-Organisms. Journal of Molecular Biology, 3, 208-218. https://doi.org/10.1016/S0022-2836(61)80047-8

[44] Altschul, S.F., Madden, T.L., Schäffer, A.A., Zhang, J., Zhang, Z., Miller, W. and Lipman, D.J. (1997) Gapped BLAST and PSI-BLAST: A New Generation of Protein Database Search Programs. Nucleic Acids Research, 25, 3389-3402. 
https://doi.org/10.1093/nar/25.17.3389

[45] Thompson, J.D., Higgins, D.G. and Gibson, T.J. (1994) CLUSTAL W: Improving the Sensitivity of Progressive Multiple Sequence Alignment through Sequence Weighting, Position-Specific Gap Penalties and Weight Matrix Choice. Nucleic Acids Research, 22, 4673-4680. https://doi.org/10.1093/nar/22.22.4673

[46] Saitou, N. and Nei, M. (1987) The Neighbor-Joining Method: A New Method for Reconstructing Phylogenetic Trees. Molecular Biology and Evolution, 4, 406-425.

[47] Felsenstein, J. (1985) Confidence Limits on Phylogenies: An Approach Using the Bootstrap. Evolution, 39, 783-789. https://doi.org/10.1111/j.1558-5646.1985.tb00420.x

[48] Tamura, K., Stecher, G., Peterson, D., Filipski, A. and Kumar, S. (2013) MEGA6: Molecular Evolutionary Genetics Analysis Version 6.0. Molecular Biology and Evolution, 30, 2725-2729. https://doi.org/10.1093/molbev/mst197

[49] Maiti, P.K. and Mandal, S. (2019) Majority of Actinobacterial Strains Isolated from Kashmir Himalaya Soil Are Rich Source of Antimicrobials and Industrially Important Biomolecules. Advances in Microbiology, 9, 220-238.

https://doi.org/10.4236/aim.2019.93016

[50] Ganesan, P., Host Antony David, R., Daniel Reegan, A., Gandhi, M.R., Gabriel Paulraj, M., Ignacimuthu, S. and Abdullah Al-Dhabi, N. (2017) Isolation and Molecular Characterization of Actinomycetes with Antimicrobial and Mosquito Larvicidal Properties. Journal of Basic and Applied Sciences, 6, 209-217.

[51] Li, Q., Chen, X., Jiang, Y. and Jiang, C. (2016) Morphological Identification of Actinobacteria. In: Actinobacteria-Basics and Biotechnological Applications, IntechOpen, London, 59-86. https://doi.org/10.5772/61461

[52] El-Tarabily, K.A., Soliman, M.H., Nassar, A.H., Al-Hassani, H.A., Sivasithamparam, K., Mckenna, F. and Hardy, G.E.S.T. (2000) Biological Control of Sclerotinia minor Using a Chitinolytic Bacterium and Actinomycetes. Plant Pathology, 49, 573-583. https://doi.org/10.1046/j.1365-3059.2000.00494.x

[53] Ouhdouch, Y., Barakate, M. and Finance, C. (2001) Actinomycetes of Moroccan Habitats: Isolation and Screening for Antifungal Activities. European Journal of Soil Biology, 37, 69-74. https://doi.org/10.1016/S1164-5563(01)01069-X

[54] Trejo-Estrada, S.R., Paszczynski, A. and Crawford, D.L. (1998) Antibiotics and Enzymes Produced by the Biocontrol Agent Streptomyces violaceusniger YCED9. Journal of Industrial Microbiology and Biotechnology, 21, 81-90. https://doi.org/10.1038/sj.jim.2900549

[55] Dashtban, M., Maki, M., Leung, K.T., Mao, C. and Qin, W. (2010) Cellulase Activities in Biomass Conversion: Measurement Methods and Comparison. Critical Reviews in Biotechnology, 30, 302-309. https://doi.org/10.3109/07388551.2010.490938

[56] Syed, D.G., Agasar, D. and Pandey, A. (2009) Production and Partial Purification of Amylase from a Novel Isolate Streptomyces gulbargensis. Journal of Industrial Microbiology and Biotechnology, 36, 189-194. https://doi.org/10.1007/s10295-008-0484-9

[57] Hwang, S.Y., Nakashima, K., Okai, N., Okazaki, F., Miyake, M., Harazono, K., Ogino, C. and Kondo, A. (2013) Thermal Stability and Starch Degradation Profile of Amylase from Streptomyces avermitilis. Bioscience Biotechnology and Biochemistry, 77, 2449-2453. https://doi.org/10.1271/bbb.130556

[58] Rajagopalan, G. and Krishnan, C. (2008) Alpha Amylase Production from Catabolic Depressed Bacillus subtilis KCC103 Utilizing Sugarcane Bagasse Hydrolysates. Bioresource Technology, 99, 3044-3050. https://doi.org/10.1016/j.biortech.2007.06.001 
[59] Reddy, N.S., Nimmagadda, A. and Rao, K.S. (2003) An Overview of the Microbial Amylase Family. African Journal of Biotechnology, 2, 645-648. https://doi.org/10.5897/AJB2003.000-1119

[60] Gupta, R., Gigras, P., Mohapatra, H., Goswami, V.K. and Chauhan, B. (2003) Microbial Amylases a Biotechnological Perspective. Process Biochemistry, 38, 1599-1616. https://doi.org/10.1016/S0032-9592(03)00053-0

[61] Pridham, T.G., Hesseltine, C.W. and Benedict, R.G. (1958) A Guide for the Classification of Streptomycetes According to Selected Groups: Placement of Strain in Morphological Sections. Applied Microbiology, 6, 52-79.

[62] Takahashi, Y. (2017) Genus Kitasatospora, Taxonomic Features and Diversity of Secondary Metabolites. The Journal of Antibiotics, 70, 506-513.

https://doi.org/10.1038/ja.2017.8

[63] De Boer, W., Klein Gunnewiek, P.J.A., Lafeber, P., Janse, J.H., Spit, B.E. and Woldendorp, J.W. (1998) Antifungal Properties of Chitinolytic Dune Soil Bacteria. Soil Biology and Biochemistry, 30, 193-203. https://doi.org/10.1016/S0038-0717(97)00100-4

[64] Chang, W.T., Chen, Y.C. and Jao, C.L. (2007) Antifungal Activity and Enhancement of Plant Growth by Bacillus cereus Grown on Shellfish Chitin Wastes. Bioresource Technology, 98, 1224-1230. https://doi.org/10.1016/j.biortech.2006.05.005

[65] Saju, K.A., Deka, T.N., Gupta, U., Biswas, A.K., Sudharshan, M.R., Vijayan, A.K. and Thomas, J. (2013) Identity of Colletotrichum Infections in Large Cardamom (Amomum subulatum Roxb.). Journal of Spices and Aromatic Crops, 22, 101-103.

[66] Shobha, K.S. and Onkarappa, R. (2011) In Vitro Susceptibility of C. albicans and $C$. neoformens to Potential Metabolites from Streptomycetes. Indian Journal of Microbiology, 51, 445-449. https://doi.org/10.1007/s12088-011-0097-2

[67] Thakur, D., Yadav, A., Gogoi, B.K. and Bora, T.C. (2007) Isolation and Screening of Streptomyces in Soil of Protected Forest Areas from the States of Assam and Tripura, India, for Antimicrobial Metabolites. Journal of Medical Mycology, 17, 242-249. https://doi.org/10.1016/j.mycmed.2007.08.001

[68] Bharti, A., Kumar, V., Gusain, O. and Bisht, G.S. (2010) Antifungal Activity of Actinomycetes Isolated from Garhwal Region. Journal of Science Engineering and Technology Management, 2, 3-9. 